\title{
THE CHINESE IN THE EARLY CAPE COLONY: A SIGNIFICANT CULTURAL MINORITY
}

\author{
Karen L. Harris \\ Department of Historical and Heritage Studies, University of Pretoria, 0002
}

\section{Die Chinese in die vroeë Kaapkolonie: 'n Beduidende kulturele minderheid}

Die Chinese Suid-Afrikaners vorm een van die kleinste kulturele erkenbare gemeenskappe in die Suid-Afrikaanse samelewing. Maar ten spyte van hierdie demografiese geringheid, en in teenstelling met die algemene opvatting, was hulle reeds van die begin van Europese heerskappy aan die Kaap in die tweede helfte van die sewentiende eeu 'n integrale deel van die land se multikulturele identiteit. Hierdie artikel gee 'n nadere blik op die teenwoordigheid en kulturele identiteit van die Chinese gemeenskap in die koloniale Kaap. Terwyl hulle 'n fisies en kultureel erkenbare en betreklik insulêre groep gebly het, was hulle een van die eerste gemeenskappe wat later in die Suid-Afrikaanse geskiedenis uitgesoek en op 'n blatante rassistiese wyse teen gediskrimineer is. Dit sal aangetoon word dat hulle eienskappe van kulturele identiteit, die wyse waarvolgens hulle uitgebeeld, beskou, behandel en teen gediskrimineer is, tot hulle kulturele sigbaarheid bygedra het, wat op sy beurt moontlik 'n kulturele samehorigheid verskans het.

Sleutelwoorde: Oorsese Chinese; kultuur; identiteit; Kaapkolonie; minderheidsgroepe; VOC; intergroepsverhoudinge

Chinese South Africans form one of the smallest culturally identifiable communities in South African society. Despite their demographic insignificance, and contrary to popular belief, they have been an integral part of this country's multicultural identity since the inception of European hegemony in the Cape in the latter half of the seventeenth century. This article proposes to take a closer look at the presence and cultural identity of the Chinese community in the colonial Cape. While remaining a physically and culturally identifiable and relatively insular group, they were later to become one of the first communities in South African history to be singled out and discriminated against in a blatantly racist manner. It will be argued that besides their own markers of cultural identity, the manner in which they were portrayed, perceived of, treated and discriminated against, contributed to their cultural visibility and in turn possibly entrenched a cultural cohesion. 
Keywords: Overseas Chinese; culture; identity; Cape Colony; minorities; DEIC; intergroup relations

\section{Culture}

Currently South Africa is renowned as a country of many cultures, it is the rainbow nation which prides itself on its diversity. ${ }^{1}$ Despite interaction over many centuries between the indigenes and foreigners this differentiation of cultures has remained. In 2008 Robert Ross wrote in the opening pages of his Concise history of South Africa that culturally, no process of homogenisation has taken place claiming that South African society is probably as diverse as ever, if not more so. ${ }^{2} \mathrm{He}$ admits that all countries are divided by the cultural background of their citizens but contends that in South Africa these splits may be sharper than ... those found elsewhere. ${ }^{3}$ This differentiation between the cultures that make up South African society - or is it societies - has been integral to the history of the region from the earliest of encounters between the first peoples. Debates persist as to the degree of isolation and acculturation that has occurred between the various peoples ${ }^{4}$ but that the independence or autonomy of cultural, religious and linguistic communities remains paramount is evident in the current Constitution of the Republic of South Africa where everyone has the right to participate in the cultural life of their choice. ${ }^{5}$

Given its current local and global prominence, it is important to note that the concept culture remains enigmatic. While definitions abound it has been said that no two anthropologists, sociologists, historians or ethno linguists agree on a common definition of the term and that defining culture remains difficult or even impossible. ${ }^{6}$ As the popularity of the use of the term has developed both within and outside of the academic domain, cultural historian Peter Burke has argued that it is increasingly

In the late 1990s the Department of Arts, Culture, Science and Technology adopted the slogan Unity in diversity, and the South African Tourism Board reiterated this by stating South Africa's cultural identity could only be described by its diversity. South African Tourism Board, Position Paper on Cultural Tourism, 1997, p. 9.

2 R. Ross, A concise history of South Africa (Cambridge, 2008), $2^{\text {nd }}$ edition, pp. 1-2.

3 R. Ross, A concise history of South Africa, 2008, p. 1.

4 See for example R. Elphick, Khoikhoi and the founding of white South Africa (Johannesburg, 1985), pp. 3-10 which discusses the persistence of the debate over the distinction between hunters and the Khoikhoi for over two and a half centuries beginning with Peter Kolbe in 1719.

5 Constitution of the Republic of South Africa, Act number 108 of 1996, chapter 2 sections 30 and 31.

6 P. Riley, Book review of J. Bayart The illusion of cultural identity in Journal of multilingual and multicultural development, 29(4), 2008, p. 348; A. Kuper, Culture the Anthropologists account (Massachusetts, 1999), p. 1. 
difficult to say what does not count as 'culture', ${ }^{7}$ while Jean-François Bayart has gone as far as posing the question in his book The illusion of cultural identity Should we stop using the word 'culture'? ${ }^{8}$ Leaving the debates aside, culture is conventionally described as the process through which people make sense of themselves and their lives, but also as the products of a specific way of living. Others argue that just about everything can qualify as culture including both the tangible and intangible which bind or give a sense of belonging to a particular identifiable grouping. ${ }^{9}$

To some extent it is agreed that all definitions of culture share one common feature and that is its human origin, the fact that humans have created it. ${ }^{10} \mathrm{Culture}$ can therefore be seen as a marker or construct of a specific community's identity and, using the phraseology of Bayart, has connotations of inclusion in terms of belongingness, but at the same time exclusion in terms of its uniqueness. ${ }^{11}$ The question arises as to how culture, and more specifically cultural identity, is constructed. It will be argued in this article that although a cultural identity is generally regarded as one that is generated from within the specific cultural grouping, this identity can be reinforced or even emanate from without. In other words, while a specific cultural grouping, and in particular a cultural minority, might adhere to a certain language or dialect, traditions, eating habits, religious practices and dress code that sets it apart from others, there are also external factors which strengthen that sense of cultural identity and distinctiveness. This ties up with another of Bayart's point - although in a different context - that the formation of a culture ... necessarily involves dialogue, and occurs in interaction with its regional and international environment. ${ }^{12}$ This, I believe, is particularly applicable and evident when the cultural grouping is a minority within the context of a larger cultural majority or diverse cultural mix. Colonization has for example, as Bayart argues, merely dramatised ... cultural pluralism by rigidifying tradition, by modifying the nature of social inequality and by introducing racial discrimination. ${ }^{13}$ The cultural minority or grouping is perceived of as different, as the 'other' and so a

\footnotetext{
P. Burke, What is cultural history? (Cambridge, 2004), p. 2.

J. Bayart, The illusion of cultural identity (London, 2005), p. 59.

J. Donald \& A. Rattansi (eds), Race, culture \& difference (London, 1992), pp. 1-2; Y. Reisinger \& L. W. Turner, Cross-cultural behaviour in tourism: concepts and analysis (Oxford, 2003), p. 4; G. Richards (ed.), Cultural tourism in Europe (Wallingford, 1996), p.21; S. Derwent, A guide to cultural tourism in South Africa (Cape Town, 1999).
}

10 A. L. Kroeber \& C. Kluckhohn, Culture: A critical review of concepts and definitions, (Massachusetts, 1952 and New York, 1985); Y. Reisinger \& L. W. Turner, Cross-cultural behaviour in tourism, 2003, pp. 4-5.

11 J. Bayart, The illusion of cultural identity, 2005, p. xii.

12 J. Bayart, The illusion of cultural identity, 2005, p. 59.

13 J. Bayart, The illusion of cultural identity, 2005, p. 61. 
process of othering takes place whereby the cultural minority is held in and relegated to a separate space - sometimes literally, but more often figuratively.

It can therefore be argued in line with Bayart's dialogue with the environment that the maintenance or strengthening of a cultural identity is also related to what overseas Chinese specialist Philip Kuhn refers to as the ecology. He uses the term ecology to refer to the way a population copes with its environment and explains that a population in a particular natural, social and economic environment at a historic time, works out an ecology of immigrant life: patters of livelihoods, technologies and social institutions. ${ }^{14}$ These aspects can also be related to the fashioning and preservation of their cultural identity. It is these various concerns that will be focused on in considering the significant place of the Chinese in the early colonial Cape.

\section{Chinese Contemplated}

Even prior to the arrival of the first Chinese individuals at the Cape,${ }^{15}$ a stereotyped perception of them was already prevalent among the Dutch who were to set up the half way station. The Dutch East India Company's (DEIC) possessions and trading in the East had brought employees into contact with Chinese in various regions such as Batavia, Sumatra, Borneo and Formosa and these encounters led to various ideas about them being introduced to the Cape. ${ }^{16}$ Before the DEIC's governing body, the Heren XVII, had actually taken the decision to establish the station at the Cape, the memorandum advocating the idea suggested that the Company gardens should be cultivated by

...some Chinese ... brought from Batavia; they are industrious

people, most of them understand gardening and there are always enough of them in irons. ${ }^{17}$

This sentiment was reiterated by the first Dutch commander at the Cape, Jan van Riebeeck, before he contemplated the importation of slaves. On 21 April 1652 merely two weeks after his arrival, he wrote to the Heren XVII, directors of the DEIC,

14 P. Kuhn, Chinese among others: emigration in modern times (Lanham, 2008), p. 2.

15 For a discussion of possible earlier encounters see K.L. Harris, Early encounters between China and Africa: myth or moment, South African Journal of Cultural History, 17(1), May 2003.

16 N. Worden, E. van Heynigen \& V. Bickford-Smith, Cape Town the making of a city (Cape Town, 1998), p. 18.

17 Remonstrantie of 1649 compiled by L. Jansen \& M. Proot in D. Moodie (ed.), The record: or a series of official papers relative to the conditions and treatment of the native tribes of South Africa (Cape Town, 1960), pp.2-3. 
requesting that some of the industrious people who had done so much to develop Java should be brought to help develop the Cape, specifying that it would not be amiss if some hard-working Chinese were to come here for that purpose ${ }^{18} \mathrm{He}$ later wrote suggesting that some married Chinese ... could be allowed on certain conditions to occupy some plots of land and also stipulated that he required a hundred Chinese ... with a knowledge of cultivating Indian produce. ${ }^{19}$ Within the next month he would repeat this request to the authorities always emphasizing the work acumen and ability of the Chinese as is apparent in one of his diary entries:

... not one hundredth part of the suitable land could possibly be cultivated because of their [Dutch] small numbers, so that an immigration of a multitude of Chinese, or other hard-working people, would be of service. ${ }^{20}$

On numerous occasions Van Riebeeck's successors, including Zacharias Wagenaar and Simon van der Stel, also repeated the request for Chinese to be brought to the Cape to assist with the agricultural and other development. ${ }^{21}$ Again, as was to become a global perception in the burgeoning colonial world of the later nineteenth century, they typified the Chinese as hard working and skilled in trades that were desperately needed - a perception that would in fact later turn against them. Needless to say, this did not transpire and while the authorities eventually decided on the importation of slaves and free Dutch to develop the refreshment station, they did on occasion indicate that they did not believe that any free Chinese could be enticed to come to such a distant land and with such uncertain prospects. ${ }^{22}$ This the Dutch authorities had got wrong, as although the number of Chinese who actually ventured to the Cape during the first centuries of European settlement and colonization was minimal, they did in fact come ${ }^{23}$.

\footnotetext{
H.B. Thom (ed.), Journal of Van Riebeeck I (Cape Town, 1952), p. 33 and fn. 5.

H.B. Thom (ed.), Journal of Van Riebeeck I, 1952, p. 35.

H.B. Thom (ed.), Journal of Van Riebeeck I, 1952, p. 35.

D. Moodie (ed.), The record: or a series of official papers relative to the conditions and treatment of the native tribes of South Africa, 1960, p.7; W.P.C. Galt, The Rand 'Crisis', Natal University Law Review 1(4), 1975, p. 191; J. C. Armstrong, The Chinese at the Cape in the Dutch East India Company period, Slave Route Conference, Cape Town, October 1997, pp. 7-8.

22 H.C.V. Leibrandt (ed.), Précis of the Archives of the Cape of Good Hope: letters and documents received, 1649-1662 I (Cape Town, 1898), pp. 84-85.

23 T. Huang, The legal status of the Chinese abroad (Taipei, 1954), p. 47.
} 


\section{Record of the Chinese}

Historian James C. Armstrong has produced the most detailed and authoritative account of the Chinese at the Cape in the DEIC period (1652-1795) ${ }^{24}$ and hence the next pages are unavoidably heavily reliant on his remarkable research. His work is based on extensive and ongoing research of the DEIC documents in the Algemeen Rijksarchief in The Hague, as well as those in the Cape Archives in Cape Town. As in most cases of cultural minorities and subaltern classes, the archival record is scant and it is only through what he calls a mosaic-building process of accumulating facts about individual lives ${ }^{25}$ that a sense of the Chinese presence at the Cape emerges. Typically the archives do not reflect proportionately on the free as opposed to the convict and exiled Chinese, as the official record is disproportionately focused on the latter. There are only a few free Chinese individuals who are more visible due to their participation in activities that converged with Dutch officialdom, such as buying or manumitting of their slaves or the details of their estates. The archive basically includes Council of Policy resolutions (resoluties), a few ordinances (plakkaten), judicial sentences (vonnissen), and in the case of the free Chinese, a small number of petitions (petisies), requests (requesten), wills (testamente) as well as figures on some of the annual censuses (opgaaf rolle). ${ }^{26}$

What makes the research process that more daunting is that the Dutch did not - as Armstrong so eloquently puts it - pardonably, have a firm orthographic grasp of Chinese names and that the

multiplicity of onomastic invention in the written records is such that an initial archival impression might lead one to think that the

Chinese population at the Cape was several times its actual size. ${ }^{27}$

Despite these problems and the paucity of the record, Armstrong has however painstakingly managed to compose an impressive account not only of the number

24 J. C. Armstrong, The Chinese at the Cape in the Dutch East India Company period paper first written in 1979 but reworked for the Slave Route Conference, Cape Town, October 1997.

25 J. C. Armstrong, The Chinese at the Cape in the Dutch East India Company period, 1997, p. 2.

26 R. Elphick and R. Shell, Intergroup Relations: Khoikhoi, settlers, slaves and free blacks, 1652-1795 in R. Elphick and H. Giliomee (eds), The shaping of South African society, 1652-1840 (Cape Town, 1989), p. 220, Figure 4.5; J.C. Armstrong, The Chinese at the Cape in the Dutch East India Company period, 1997, pp. 2-3, 12, 15.

27 J.C. Armstrong, The Chinese at the Cape in the Dutch East India Company period, 1997, p. 4. 
and names of Chinese present, but also succeeded in reconstructing a more composite picture of the lives of a few of these Chinese individuals. ${ }^{28}$

In addition to this historical work, we also have the anecdotal writings of some of the early travellers to the Cape, such as J. Barrow, O.F. Mentzel, G. Thompson and C. Thunberg, who included relatively detailed descriptive accounts of the Chinese they encountered. ${ }^{29}$ Although these accounts were for all intent and purposes true renditions of their travels and experiences, one can not help but suggest that, given the apparently small size of the number of Chinese at the Cape, these were probably also to add a little colour to the records of their travels. The exotic was already very much part of a growing Western fascination. In the same vein, invariably paintings of the period also depicted scenes with Chinese (and Malays) in the streets and along the shores as small-scale traders, fishermen and craftsmen of sorts. The added identifiable oriental touch in the form of the conical straw hats or toerangs ${ }^{30}$ as well as the typical Eastern dress, was possibly also to an extent a stroke of artistic license. The written record of Chinese present at the Cape does not really corroborate this distinct prevalence alternately, the archival record may under represent their presence.

\section{First Chinese - DEIC}

In 1654 the first Chinese convicts were exiled to the Cape and they were to continue to arrive intermittently in small numbers over the next one and a half centuries. ${ }^{31}$ Based on his archival studies, Armstrong estimates that during the DEIC period there were no more than about 350 Chinese present at the Cape and at any one time they probably

28 J.C. Armstrong, The Estate of a Chinese Woman in the Mid-Eighteenth Century at the Cape of Good Hope, Journal of Chinese overseas, May 2008, pp. 111-126. He also includes a number of detailed profiles in his paper.

29 J. Barrow, An account of travels into the interior of southern Africa II (London, 1804); J. Barrow, A voyage to Cochinchina in the years $1792-1793$ (London, 1806); O.F. Mentzel, A geographical and topographical description of the Cape of Good Hope I and II (Cape Town, 1921 and 1925); V.S. Forbes, Travels and adventures in Southern Africa by George Thompson II \& III (Cape Town, 1968); G. Thompson, Travels and adventures in Southern Africa I (London, 1827); C. Thunberg, Travels in the Cape of Good Hope (Cape Town, 1986).

30 R. Elphick \& R. Shell, Intergroup Relations: Khoikhoi, settlers, slaves and free blacks, 1652-1795, 1989, p. 223 state that Chinese and Malay traders were easily identified by their conical straw hats or toergangs; N. Worden, E. van Heynigen \& V. Bickford-Smith, Cape Town the making of a city, 1998, p. 128 refer to this hat as the toedang and describe it as follows: The toedang was worn by both men and women in the East Indies, but appears to have been used only by men at the Cape. This type of headgear was noted by visitors from as early as 1772 as a marker of Islam.

31 J.C. Armstrong, The Chinese at the Cape in the Dutch East India Company period, 1997, p. 13; M. Upham, The First Recorded Chinese and Japanese at the Cape, Capensis 2(97), April 1997, p.10. 
never exceeded $50 .{ }^{32}$ Although this figure is small, it remains proportionately significant given that by 1731 the number of DEIC employees at the Cape only reached 959 and the free burghers numbered $585 .{ }^{33}$ According to Armstrong the majority of Chinese present were political and other unwanted exiles, as well as convicts banished to the Cape from the DEIC headquarters in Batavia. Their names, arrival dates and periods of sentence often featured in the legal record and the crimes for which they were sentenced ranged from theft and extortion to assault and murder. ${ }^{34}$ While some of these Chinese served their sentences as forced labourers, others who were exiled to the Cape ... as condemned persons [had] the charge that they were to ... earn [their] own keep..$^{35} \mathrm{An}$ interesting development that Armstrong identifies through his meticulous research and one which was not regulated by a plakkaat (ordinance) - is that a time-expired convict became a free exile (vry banneling). This meant that they occupied a kind of limbo between convicts and free burghers, with some Chinese actually progressing to the latter status as their names are found on the opgaaf rolle. ${ }^{36}$

The experiences of an exile or convict were often very much like that of a slave - they were treated, housed and worked the same. Armstrong notes that a number of these Chinese convicts were actually assigned to DEIC high officials probably as a perequisite, and remained with them for extended periods of time suggesting that their job performance as fishermen, basket makers and masons, must have been satisfactory. ${ }^{37}$ The small number of free Chinese individuals who might have arrived at the Cape either of their own accord or came ashore from passing ships, was as explained above, augmented by ex-convicts and exiles who had served their sentences or been pardoned and could not afford to return home. ${ }^{38}$ They lived apart from the other free blacks (free persons of African or Asian descent) and even had their own

32 J.C. Armstrong, The Chinese at the Cape in the Dutch East India Company period, 1997, pp. 4-5 and Figure 1.

33 N. Worden, E. van Heynigen \& V. Bickford-Smith, Cape Town the making of a city, 1998, p. 50.

34 H.F. Heese, Reg en onreg, Kaapse regspraak in die Agtiende Eeu (Bellville, 1994), pp. 48-49, 240, 263; J.C. Armstrong, The Chinese at the Cape in the Dutch East India Company period, 1997, pp. 8, 16.

35 J.C. Armstrong, The Chinese at the Cape in the Dutch East India Company period, 1997, pp. 12, 21.

36 J.C. Armstrong, The Chinese at the Cape in the Dutch East India Company period, 1997, p. 12.

37 J.C. Armstrong, The Chinese at the Cape in the Dutch East India Company period, 1997, pp. 20-21, 29-31.

38 H.L. Pineo, Chinese diaspora in western Indian Ocean (Mauritius, 1985), p. 210; T. Huang, The legal status of the Chinese abroad, 1954, p. 47; R. Elphick \& R. Shell, Intergroup Relations: Khoikhoi, settlers, slaves and free blacks, 1989, p. 217. 
separate cemetery in Cape Town. ${ }^{39}$ These individuals made a living from a range of small-scale trading activities in eastern goods, fresh produce, fish and confectionary, while Armstrong has record of a Chinese goldsmith. ${ }^{40}$

The contemporary traveller accounts provide a vivid portrayal of the Chinese activities in everyday life of the early Cape. In the early eighteenth century Mentzel described the Chinese restaurateurs as:

...expert fisherman as well as good cooks. Fried and pickled fish with boiled rice is well favoured by soldiers, sailors and slaves. When the fierce North-Westers blow, crayfish, crabs, seaspiders and "granelen" [small crabs] are cast ashore. They are zealously collected by these Orientals, cooked and sold... These Asiatics likewise keep small eating houses where tea and coffee is always to be had; they specialise in the making of kerri-kerri [mutton stew].

One need not be squeamish in patronising their cook-shops since they keep the places scrupulously clean and do not touch the food with their fingers. ${ }^{41}$

He also describes their candle making:

The Chinese are the only candle makers at the Cape, for though the homemade farm candle is serviceable, it cannot be compared in appearance with the handiwork of the Chinamen. Though made of mutton fat are as white and well-shaped as wax candles. ${ }^{42}$

That some of these small scale Chinese entrepreneurs were successful and reasonably wealthy is evident from the registers that list them as slave owners as well as from the wills that record their many possessions.$^{43}$ It was also apparent in the responses they elicited from the Europeans, as well as the evidence in the legal record. In 1727, for example, nine licensed European bakers petitioned that

39 C. Thunberg, Travels in the Cape of Good Hope (Cape Town, 1986), p. 49, fn. 147; O.F. Mentzel, $A$ geographical and topographical description of the Cape of Good Hope I (Cape Town, 1921), pp. 14, 128.

40 J.C. Armstrong, The Chinese at the Cape in the Dutch East India Company period, 1997, p. 35.

41 O.F. Mentzel, A geographical and topographical description of the Cape of Good Hope II (Cape Town, 1921), p. 92.

42 O.F. Mentzel, A geographical and topographical description of the Cape of Good Hope II, 1921, p. 92.

43 O.F. Mentzel, A geographical and topographical description of the Cape of Good Hope II, 1921 , p. 150; J.C. Armstrong, The Chinese at the Cape in the Dutch East India Company period, 1997, pp. $38-42$. 
certain burghers and Chinese were in the habit of sending their boys about the streets to sell different sorts of cakes, and [prayed] that this should be forbidden as it [caused] the memorialists great injury. ${ }^{44}$

The authorities responded by introducing an ordinance (plakkaat) that forbade the Chinese from continuing the practice and imposed a fine of 50 rixdollars for transgression, prohibited personal baking for a year and stipulated that the seized baked products were to be donated to the Company hospital. ${ }^{45}$ That the activities persisted is evident in the fact that the ordinance was reissued in 1740 to the same effect and in 1779 another ordinance imposed a fine of 25 rixdollars on any Chinese who sold fresh fruit, vegetables and meat from small boats to ships in Table Bay. ${ }^{46}$ Despite the authorities intervention, Armstrong comments that the small free Chinese community had become increasingly visible and prosperous, so much so that even the insurrectionist Estiénne Barbier complained in 1739 that the Cape authorities favoured not only unbaptised Khoikhoi, but also Chinese above white men. ${ }^{47}$

Matters were however not improved by the fact that there were those Chinese who were involved in less reputable activities, such as the buying and selling of stolen goods as well as allegations of Chinese cheating the too credulous slaves. ${ }^{48}$ The vehement reaction from the European settlers was apparent in a petition of 1779 in which they demanded that no Chinese, Javanese or convicts belonging to Robben Island should live among the burgers and trade or keep shops, since they above and beyond all other reason tempt slaves to thievery. ${ }^{49}$ Reacting to these allegations about the Chinese, Mentzel argued that it was:

dangerous to generalise and condemn them all as rogues [as] some of them will show more consideration to those who owe them money than

44 G.C. de Wet (red.), Suid-Afrikaanse argiefstukke: resolusies van die politieke raad VII, 1971, pp. 308-309; Translation in R. Elphick \& R. Shell, Intergroup Relations: Khoikhoi, settlers, slaves and free blacks, 1989, p. 223.

45 K.M. Jeffries \& S.D. Naude (eds), Kaapse argiefstukke: Kaapse plakkaatboek, 1707-1753 II (Kaapstad, 1948), p. 121.

46 K. M. Jeffries \& S. D. Naude (eds), Kaapse Argiefstukke: Kaapse plakkaatboek, 1707-1753 II, 1948, p. 121; K. M. Jeffries \& S. D. Naude (eds), Kaapse Argiefstukke: Kaapse plakkaatboek,1754-1786 III (Kaapstad, 1949), p. 101.

47 J.C. Armstrong, The Chinese at the Cape in the Dutch East India Company period, 1997, p. 37 quoting from G.M. Theal (red.) Belangrike historische dokumenten I (Kaapstad, 1896), pp. 1-4.

48 R. Elphick \& R. Shell, Intergroup Relations: Khoikhoi, settlers, slaves and free blacks, 1989, p. 223; O.F. Mentzel, A geographical and topographical description of the Cape of Good Hope II, 1921, pp. 91-2, 150 .

49 J.C. Armstrong, The Chinese at the Cape in the Dutch East India Company period, 1997, p. 58. 
Europeans do. He [had] met people to whom Asiatic dealers had given various commodities ... on long credit, even until their return from Holland. ${ }^{50}$

He added that on the whole, these Chinese live a humble quiet and orderly life at the Cape. ${ }^{51}$ Based on his extensive research, Armstrong substantiates this view by claiming that contrary to the view of contemporary observers the free Chinese did not appear to run afoul of the law very often. ${ }^{52}$ This sentiment was also borne out by the fact that three ordinances were issued in 1722, 1727 and 1740 by the DEIC authorities specifying that the Chinese and free blacks living in Table Valley should be formed into a company, with officers from their ranks, to be used in the event of public catastrophes such as fire or ships stranding in Table Bay. ${ }^{53}$

Yet, by the end of the DEIC period, the Chinese appeared more conspicuous and there is evidence that they were being regarded with contempt by members of Dutch settler society, despite their drastically diminishing numbers. Based on the available opgaaf rolle, Armstrong's data shows a decline from the mid eighteenth century that left the Chinese numbers almost negligible by the time the British took over the Cape ${ }^{54}$ Commenting on their status during this period, Armstrong poignantly points to the fact that in one eighteenth century official opgaaf rol the Chinese were listed last after the free blacks as a kind of unassimilated appendage of the free black community $^{55}$ - a position which indeed graphically reflected their position.

\section{First Chinese - Transitional governments}

During the period 1795 to 1814 the Cape Colony was governed by three governments: British (1795-1803), Batavian (1803-1806) and British (1806-1814) before finally becoming a British colony thereafter. Bill Freund has aptly called this period the transitional years recognising the three phases as distinct, but arguing for remarkable

50 O.F. Mentzel, A geographical and topographical description of the Cape of Good Hope II, 1921, p. 150.

51 O.F. Mentzel, A geographical and topographical description of the Cape of Good Hope II, 1921, p. 150.

52 J.C. Armstrong, The Chinese at the Cape in the Dutch East India Company period, 1997, p. 60

53 J.C Armstrong, The Chinese at the Cape in the Dutch East India Company period, 1997, p. 35.

54 J.C Armstrong, The Chinese at the Cape in the Dutch East India Company period, 1997, pp. 32-33, 61.

55 J.C Armstrong, The Chinese at the Cape in the Dutch East India Company period, 1997, p. 61. 
continuity in economic, social and administrative concerns. ${ }^{56}$ The period thereafter under British colonial rule can be described very generally as one of the attempts at consolidation within the context of new social and economic forces emanating from both inside and outside the Colony. ${ }^{57}$ The archival record of the Chinese during these various periods is even more scant than under the Dutch, and it is again traveller accounts as well as sundry official correspondence, that offer a glimpse, albeit onesided, of the Chinese at the Cape.

Like the Dutch, the British East India Company (BEIC) was involved in the Far East from as early as the 1600s both for trade and labour purposes, and the officials and employees were therefore equally aware of Chinese working abilities. In contrast to the DEIC period, the retrieved requests for imports of Chinese to the Cape Colony during the first century of British occupation did not emanate primarily from government officials, but also individual settlers. For the most part of the nineteenth century, the number of Chinese appears to remain lower than during the DEIC period, probably because the BEIC did not increase their numbers by exiling convicts from other British colonial possessions to the Cape. ${ }^{58}$ By the end of the century the number of Chinese enumerated on the Statistical Register of the Colony of the Cape of Good Hope, 1891, was 215. This was the first census since the inception of the Census Act in 1856 that specifically listed the Chinese as a subsection of the Race termed Mixed and Other ${ }^{59}$ At this time the rest of the population, including European and White, Malay, Hottentot, Fingo, Kafir and Bechuana, totalled at $1527224 .{ }^{60}$

One of the first recorded British colonial references to the Chinese was made in 1804 by the British official and traveller, John Barrow. Faced with a dismal economy, he declared that the most effective way to improve the Cape would be the introduction of Chinese. He believed that

\section{[w]ere about ten thousand of this industrious race of men distributed over the Cape district, and those divisions of Stellenbosch and Drakenstein ... the face of the country would exhibit a very different appearance in the course of a few years; the markets would be better}

\footnotetext{
56 W. Freund, The Cape under the transitional governments, 1795-1814 in R. Elphick and H. Giliomee (eds), The shaping of South African society, 1652-1840, 1989, pp. 324-327.

57 J.B. Peires, The British and the Cape, 1814-1834 and W. Freund, The Cape under the transitional governments, 1795-1814 in R. Elphick \& H. Giliomee (eds), The shaping of South African society, 1652-1840, 1989, pp. 327, 472.

58 K.L. Harris, A history of the Chinese in South Africa to 1912 (D.Litt. et Phil., Unisa, 1998), chapter 2 .

59 Statistical register of the colony of the Cape of Good Hope, 1891, Part II, p. 4.

60 Statistical register of the colony of the Cape of Good Hope, 1891, Part II, p. 23.
} 
supplied, and an abundance of surplus produce acquired for exportation. ${ }^{61}$

Barrow had recently travelled to China and various colonies in the Far East and therefore had first-hand experience of the abilities of Chinese agriculturalists. ${ }^{62}$ Like his Dutch predecessors at the Cape, he berated the Europeans in the colonies for becoming the most indolent and prodigal of all other nations and noted that:

in Batavia the Dutch are still more indolent ... [and] were it not for the Chinese the Europeans must literally starve. These industrious people exercise all manner of trades and handicraft work, cultivate the ground, supply the market with vegetables, with butcher's meat, and with poultry; raise rice, pepper, coffee, and sugar, for consumption and exportation; carry on the whole commerce of the island both internal and coastways; act as brokers, factors, and interpreters between the Dutch government and the natives; farm, and collect, the taxes and revenues, both for the former and the latter; in a word, they possess among themselves the monopoly of the whole island. ${ }^{63}$

Barrow's enthusiasm for Chinese labour was so great that he claimed that [t]en thousand Chinese, transported to the Cape of Good Hope, would prove a more valuable gold mine to the colony, than those which are supposed to exist. ${ }^{64}$

In a report on the Cape Colony submitted to the British government in 1809, commissioner Richard Collins, an influential British official, added his support to the cause. He wrote that this country should ... be given out to industrious Europeans or Chinese, who might gain a good livelihood by the cultivation of corn and felling of wood. ${ }^{65}$ These sentiments were later echoed by settlers on the eastern Cape frontier. In a memorial on their behalf, C.B. Smith informed the colonial secretary that to remedy the labour question on the frontier they should follow the examples of other

61 J. Barrow, An account of travels into the interior of southern Africa II (London, 1804), pp. 430-1;

J. Barrow, Travels in to the interior of southern Africa II, 1806, p. 150.

62 J. Barrow, Travels in China (London, 1804); J. Barrow, A voyage to Cochinchina in the years 17921793 (London, 1806).

63 J. Barrow, An account of travels into the interior of Southern Africa II, 1804, p. 29.

$64 \mathrm{~J}$. Barrow, An account of travels into the interior of Southern Africa II, 1804, p. 30.

65 D. Moodie (ed.), The record: or a series of official papers relative to the conditions and treatment of the native tribes of South Africa, 1960, pp. 16, 28. 
colonies, Queensland, Mauritius and the West Indies, for instance, and import Chinese or Indian coolies, but argued in favour of the Chinese because:

as a labourer and a general servant the China-man is unsurpassed and he possesses the virtue of sobriety which the coolie does not; he possesses more stamina; he is more cosmopolitan in his habits and adapts himself without murmuring to any condition of life provided he is paid for it ${ }^{66}$

In the 1820 s, the traveller George Thompson made equally positive observations about the advantages of importing Chinese settlers claiming that these industrious people as artificers, mechanics, and domestic servants would be in many situations a great acquisition. ${ }^{67}$

The authorities responded in different ways to this advice and requests for Chinese. Sometimes they argued that the introduction of Chinese in any number [would be] a step fatal to the future of this colony destroying as it would any hope of creating an European population other than capitalists and land owners. ${ }^{68}$ And at other times they indicated that the extensive emigration from China was indeed a matter for serious enquiry but that it would appear to be attended with many difficulties and dangers, and therefore it would not be expedient for the Cape Colony. It was also pointed out that it would be difficult to secure Chinese labour, as it had better and more lucrative options in colonies such as Queensland in Australia. ${ }^{69}$ It has also been suggested that the authorities believed that the Chinese did not much relish the idea of working at the Cape, where they were so likely to be confused with Malays and Coloured slaves. ${ }^{70}$

The British authorities were obviously not entirely averse to the idea of importing Chinese to the Cape and as a result permission was given intermittently for the arrival of a number of Chinese artisans throughout the nineteenth century. ${ }^{71}$ For example, in 1814, 23 Chinese craftsmen were privately brought to Simonstown to build Captain T.T. Harington's house and establish his gardens. ${ }^{72}$ To alleviate the shortage of labour

66 Cape Archives (hereafter CA), Cape Town: Colonial Office (CO) 4227, S122: Memorial: C.B. Smith. Recommending Chinese Immigration, 1882-10-09.

67 G. Thompson, Travels and adventures in southern Africa I (London, 1827), p. viii.

68 CA: CO 4227, S122: Memorial: Reply from Colonial Secretary's Office, Cape Town, 1882-10-16.

69 CA: Government House (GH) 1/234, 72: Papers Received from Secretary of State, London, General Despatches Discouraging the Introduction of Chinese Emigrants to the Cape, 1853-06-11.

70 R. Lewcock, Early nineteenth century architecture in South Africa: a study of the interaction of two cultures, 1795-1837 (Cape Town, 1963), p. 375 quoting CO 68/553, 1815-12-06.

71 For example see CA: CO 4068, 214: Memorials received: H. Cloete. Relative to Importation of Chinese Labourers, 1853-12-29.

72 M. Yap \& D. Mann, Colour, confusion and concessions (Hong Kong, 1996), pp. 11-12. 
in the building industry, 24 Chinese signed an agreement in 1815 with the Royal Navy at Canton River, to work for three years at the Cape. The group comprised of two foremen, twelve masons, nine carpenters and a painter. They were involved in building the Drostdy at George and the belfry and wooden campanile of the chapel in the naval yard at Simonstown. In 1822 just under half of them were still in fixed employment with government and private individuals in Cape Town and Knysna. ${ }^{73}$ In 1849 a British colonist, M.J.O. Smith, recruited a few Chinese to work as gardeners, cooks and carpenters. ${ }^{74}$ The Cape administrators also made official requests for Chinese labourers, and resolutions to that effect were passed by the Cape Legislative Assembly in 1874 and 1876. Four hundred Chinese labourers had already been contracted when the British government vetoed this decision..$^{75}$ In the early 1880 s there is also record of an agent contracting 126 Chinese to work on the railway line between Cradock and Colesburg in the eastern Cape. ${ }^{76}$

The reaction to the arrival of these various imports of Chinese was ambivalent - while at one level their work acumen was praised and welcomed, at another there was evidence of hostility and scorn. It appears as though most of the more negative reactions emerged towards the end of the nineteenth century and took the form of newspaper reports such as the one in the Graaff-Reinet Advertiser of 1881 which made dark predictions on the future of the colony if this moral plague was allowed to gain a foothold..$^{77}$ These sentiments and rhetoric were very much in line with attitudes that were surfacing in colonies on both sides of the Atlantic and Pacific Oceans, ${ }^{78}$ where Chinese immigrants were as much welcomed as they were objected to ${ }^{79}$

Unlike the DEIC period, for most of the nineteenth century the archival record remains relatively mute on the arrival of non-contracted or independent Chinese individuals. After 1795 the censuses (opgaaf rolle) are apparently incomplete as

73 CA: CO 68/451 Contract Agreements, Canton River, 1815-04-09; CO 166/18, Correspondence, 182203-30.

74 The Herald, 1849-01-20.

75 CA: GH 1/358, 16: Papers Received from Secretary of State for London: General Despatches. Introduction of 400 Chinese labourers into the Cape Colony, 1876-02-15; GH 23/33, 25: Papers Despatched to Secretary of State, London General Despatches, 1875-12-15.

76 M. Yap \& D. Mann, Colour, confusion and concessions, 1996, pp. 18-20 reference Eastern Province Herald, October-November 1882.

77 M. Yap \& D. Mann, Colour, confusion and concessions, 1996, pp. 16-19.

78 K.L. Harris, 'Not a Chinaman's Chance': Chinese labour in South Africa and the United States of America, Historia 51(2), November 2006.

79 H.F. Mac Nair, The Chinese abroad: their position and protection (Shanghai, 1924), p. vii. 
the DEIC system probably broke down ${ }^{80}$ and thus even the numerical records of the subaltern or lower echelons of society are lacking. Also, as indicated above the census system introduced in the mid 1860 s seldom enumerated the Chinese as a separate category, thereby keeping them indistinguishable. Moreover, up to the end of the nineteenth century there were no colonial regulations or laws relating specifically to the Chinese at the Cape, arguably due to their limited numbers and the resultant absence of direct competition between them and the settlers, thus making it difficult to detect them and determine their positions. From the end of the nineteenth century, however, there is a dramatic increase in the emigration if Chinese overseas throughout the world, and the Cape is to receive some of these new arrivals. ${ }^{81}$

\section{Chinese cultural identity}

This article has presented an overview of the place and perception of the Chinese in the Cape for an extended period of over two centuries. In the discussion, the Chinese, for all intent and purposes, despite their miniscule numbers, are often accorded separate reference and treatment. It is this perception, or construction, of the Chinese that has persisted over time, regardless of the variants that might or might not exist, to which I now turn.

The Chinese do indeed all emanate from one geographical location, albeit one that is incredibly vast and exceedingly diverse, they also share similar mongoloid physical features and to a large extent have an affiliation with the concept of an ancestral village or province with China remaining All Under Heaven.$^{82}$ However, there are vast variations in terms of aspects such as language that go way beyond dialect; traditional dress differs; and certain regions celebrate different customs and other markers of cultural cohesion. ${ }^{83}$ Yet to the outsider, the Westerner or Occident, there is a blanket Chinese, which both then and now, has been used to label them probably more so than other nomenclatures. While it may be argued that this is indeed the case with all culturally identifiable groupings and that variants always persist, it is suggested that it was this cultural construction of the Chinese, both at the Cape and

80 R. Shell, Children of bondage: a social history of the slave society at the Cape of Good Hope, 16521838 (Johannesburg, 1994), p. 441.

81 K.L. Harris, The Chinese in South Africa: A preliminary overview to 1910, Kleio XXVI, 1994, pp. 9-26.

82 With acknowledgment to D. Accone, All under heaven: the story of a Chinese family in South Africa (Cape Town, 2004).

83 See for example the discussion regarding differences between the ethnically distinguishable Cantonese and Moiyeanese as regards dialect and customs, as well as the traditional animosity in M. Yap \& D. Mann, Colour, confusion and concessions, 1996, pp. 32-34. 
elsewhere, that entrenched a perception in popular consciousness that would lead to an even greater degree of ostracization than with other cultural communities.

As is evident, the Chinese in the Cape Colony were always only present in small numbers and arrived randomly mainly as individual exiles and convicts or independent entrepreneurs. In these early years at the Cape they do therefore not appear as one large homogenous group - as was the case in many other destinations that they ventured to. Despite this, they are always referred to as a single cohesive cultural group; in the opgaaf rolle and censuses they are sometimes even categorized and enumerated apart from other free blacks; they appear to live in separate areas of Cape Town; and have a specific burial ground (Figure 1).

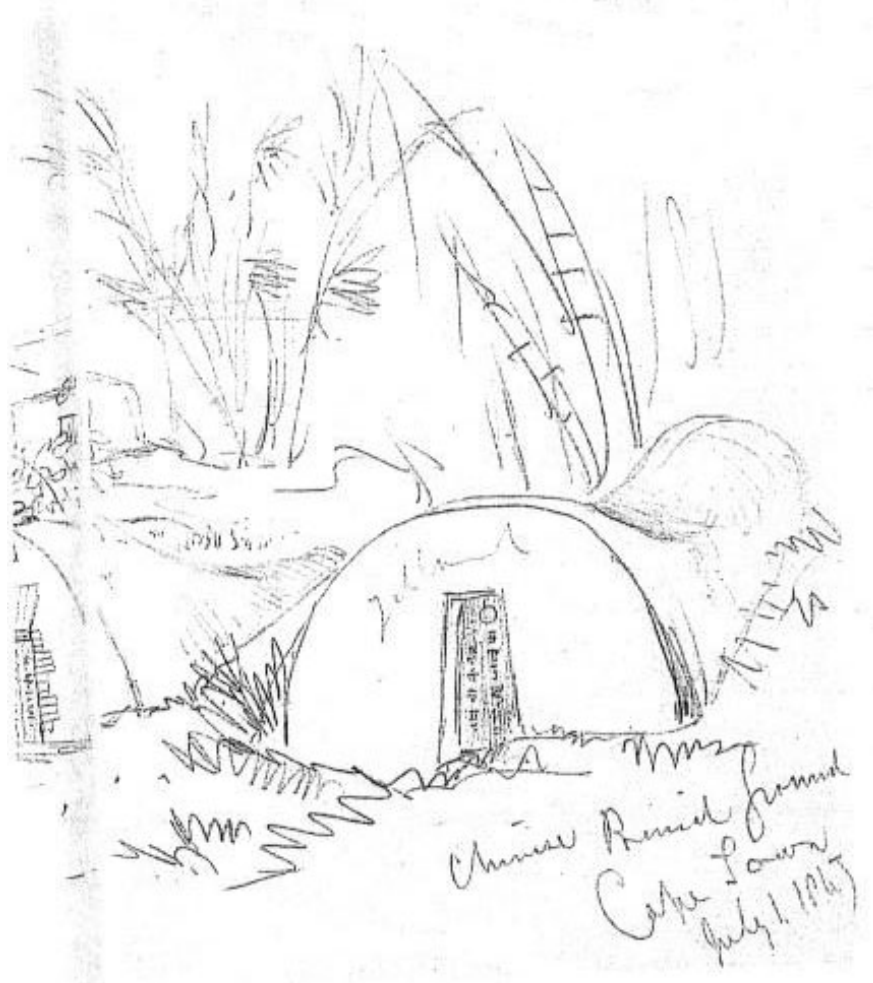

Figure 1: Drawing by George French Angas of the Chinese burial ground on Signal Hill, 1 July 1843.

(The Brenthurst Press ART. 18/5) 
Armstrong points out that, unlike the free blacks and slaves who are listed and identified by their place of origin (typonym), this was not always done in the case of the Chinese who were merely referred to as "Chinees". ${ }^{84}$ Furthermore, in the DEIC period the Chinese are singled out for specific sets of legislation, while throughout the period under consideration they are both admired and defied as a cultural group with particular characteristics or traits.

The cultural identity of the Chinese at the Cape was indeed built from within, but I would argue was buttressed from without. In other words, given their inherent Chineseness, they also became more conspicuous and significant as a cultural minority in terms of the environment they were in and the dialogue they had with the other. Ultimately this would contribute to the emergence of growing anti-Sinitic sentiments that would culminate in the Chinese being the first culturally identifiable community in South Africa to be discriminated against in a blatantly racist manner - the Chinese Exclusion Act of 1904. This, it can be argued, would be perpetuated throughout the century and beyond where, as recently as last year, the South African Chinese community would find themselves embroiled in a bitter legal battle over their status and position in South Africa's multicultural society. ${ }^{85}$

84 He explains that perhaps it was felt that Chinese names were sufficiently distinctive to need no further qualification by place of origin. J.C. Armstrong, The Chinese at the Cape in the Dutch East India Company period, 1997, pp. 62-64.

85 For a discussion of this debacle see K.L. Harris, The Chinese crisis, BEE and the past, unpublished paper, Bi-annual Conference of the South African Historical Association, History and Crisis, Rhodes University, July 2008. 